\title{
Wind Powering America: A Key Influence on U.S. Wind Market
}

The U.S. Department of Energy's Wind Program is committed to developing and deploying a portfolio of innovative technologies for clean, domestic power generation to support an ever-growing industry, targeted at producing $20 \%$ of our nation's electricity by 2030 .

\section{Wind Powering America}

The U.S. Department of Energy (DOE) established the Wind Powering America (WPA) initiative in 1999 to educate, engage, and enable critical stakeholders to make informed decisions about how wind energy contributes to the U.S. electricity supply. The primary objective of WPA was to help the United States achieve 10 gigawatts $(\mathrm{GW})$ of installed wind capacity by 2010 , and specifically to help 30 of 36 targeted states achieve greater than $100 \mathrm{MW}$ of installed capacity.

WPA's focus areas included state-based activities-state wind working groups, anemometer loan programs, wind resource maps, workshops and conferences, and state-specific material development - as well as rural economic development activities, public utility partnerships, and a Greening Federal Loads effort. The initiative targeted an increasing number of states over time.

\section{Assessing Impacts}

In July 2013, DOE completed an evaluation of the effectiveness of the WPA initiative. The study employed an

\section{Estimates of WPA's Influence and Percent of Overall Wind Capacity Additions}

\begin{tabular}{|r|r|r|}
\hline $\begin{array}{c}\text { Market / Activity } \\
\text { Category }\end{array}$ & $\begin{array}{c}\text { Estimated Share } \\
\text { of Influence on } \\
\text { Capacity (MW) }\end{array}$ & $\begin{array}{c}\text { Total Capacity } \\
\text { Added (MW) }\end{array}$ \\
\hline Utility-Scale Market & $\mathbf{3 , 3 5 0}$ & $\mathbf{2 2 , 5 4 6}$ \\
\hline State-Based Activities & 2,306 & \\
\hline Other WPA Activities & 1,044 & \\
\hline Small Wind Market & $\mathbf{2 4 . 6}$ & $\mathbf{1 0 5 . 6}$ \\
\hline State-Based Activities & 18.1 & \\
\hline Other WPA Activities & 6.5 & \\
\hline All Markets and & $\mathbf{3 , 3 7 5}$ & $\mathbf{2 2 , 6 5 2}$ \\
\hline Activities & $(\mathbf{1 4 . 9 \% )}$ & \\
\hline
\end{tabular}

investigative approach that included historical tracing, questionnaires, and in-depth interviews of key stakeholders in states with and without WPA wind working groups.

The evaluation found that WPA activities positively influenced a combined total of approximately $3,375 \mathrm{MW}-$ nearly $15 \%$ - of utility-scale and small wind capacity additions made by target states. More than 2,300 MW of that amount was tied to WPA's state-based activities, and more than 1,050 MW was attributed to WPA's activities contributing to public-private partnerships.

The evaluation included a survey of key stakeholders in the wind power community. Some of the key findings include:

- Seventy-one percent of interviewees responded that WPA activities had an influence in their state, with a similar share indicating that their states would have seen less wind capacity installed or projects delayed without WPA's intervention.

- Stakeholders in Iowa, New York, and Texas - three states not targeted by WPA-attributed an average of nearly $8 \%$ of their utility-scale capacity additions to influence from WPA's activities, including formation of Wind Working Groups, in neighboring states.

- Stakeholders in states with successful Wind Working Groups felt WPA's most important activities are those aimed at either increasing public support or building networks to facilitate information sharing.

- WPA's role as a trusted, unbiased repository and provider of technical information is a key driver of success in wind development.

\section{Moving Forward}

The evaluation concluded that the Wind Program can leverage WPA's reputation as a provider of objective and credible technical information to address current and emerging barriers to the continued large-scale deployment of wind capacity, particularly in states where the market is already developed. Further, the program can build off of WPA's name recognition, networks, and successes to influence markets through stakeholder engagement and expanding partnerships with universities and other organizations.
U.S. DEPARTMENT OF ENERGY

Energy Efficiency \& Renewable Energy
For more information, visit: eere.energy.gov/analysis/pdfs/wind_powering_america_evaluation_2013.pdf.

DOE/GO-102013-4117 • September 2013

Printed with a renewable-source ink on paper containing at least $50 \%$ wastepaper, including $10 \%$ post consumer waste. 